
10. Nordic Council
of Ministers

Shipments of green-listed waste

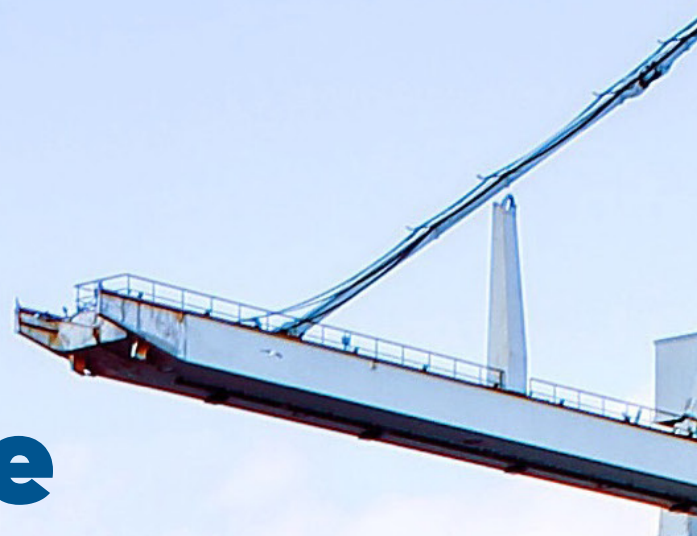

\title{
a Nordic survey
}

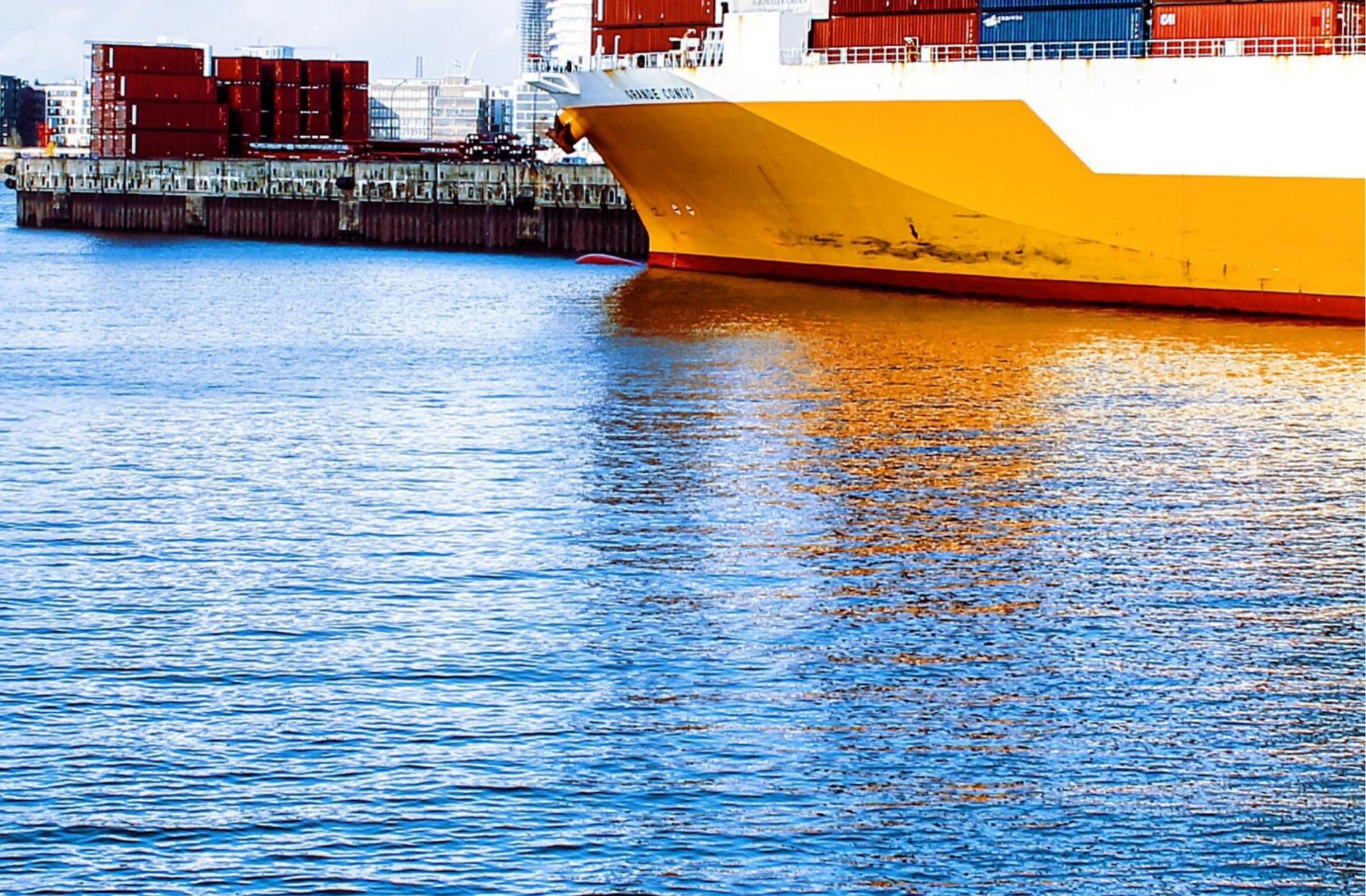





\section{Shipments of green-listed waste}

a Nordic survey

Emma Nurmi, Dorte Skjøtt Jakobsen, Beate Langset,

Margareta Eriksson, Pär Kollberg and Kaija Rainio.

TemaNord 2016:566 


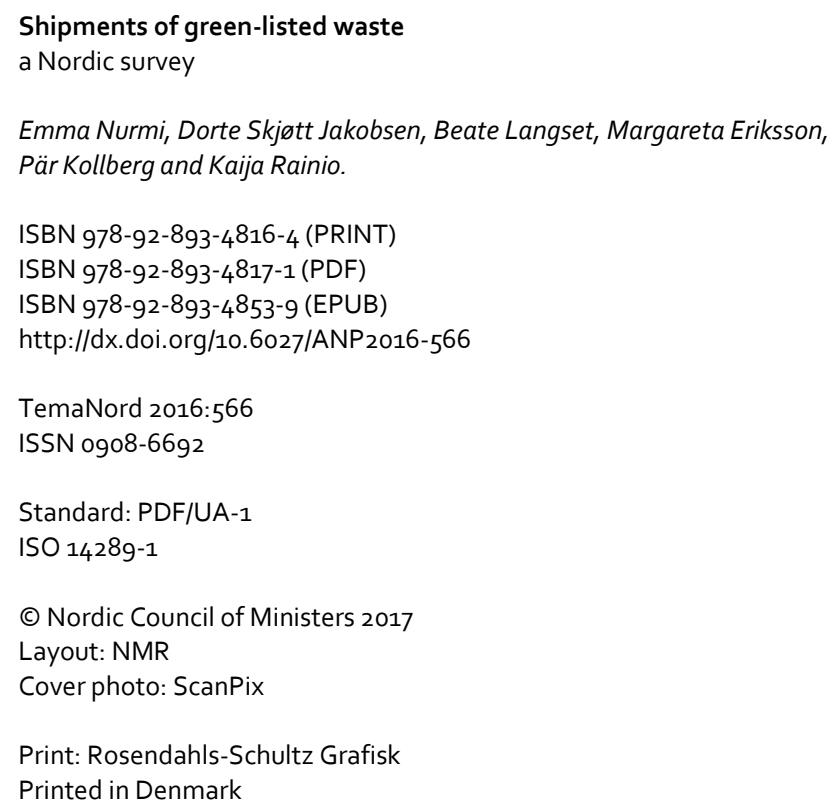

Although the Nordic Council of Ministers funded this publication, the contents do not necessarily reflect its views, policies or recommendations.

\section{Nordic co-operation}

Nordic co-operation is one of the world's most extensive forms of regional collaboration, involving Denmark, Finland, Iceland, Norway, Sweden, the Faroe Islands, Greenland, and Åland.

Nordic co-operation has firm traditions in politics, the economy, and culture. It plays an important role in European and international collaboration, and aims at creating a strong Nordic community in a strong Europe.

Nordic co-operation seeks to safeguard Nordic and regional interests and principles in the global community. Shared Nordic values help the region solidify its position as one of the world's most innovative and competitive. 


\section{Contents}

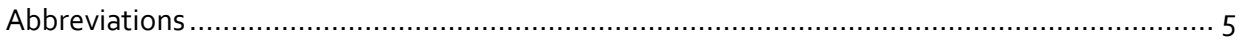

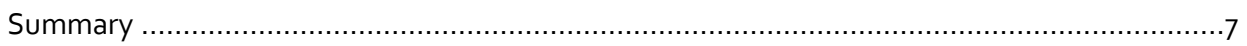

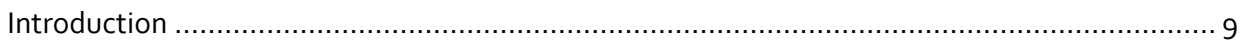

The Waste Shipment Regulation and green-listed waste shipments .............................. 9

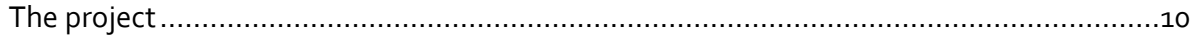

1. Country-specific information on shipments of green-listed waste ..............................13

1.1 The authorities in the project countries and their duties related to

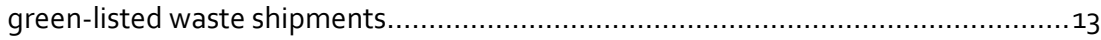

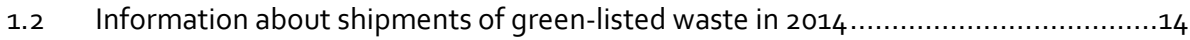

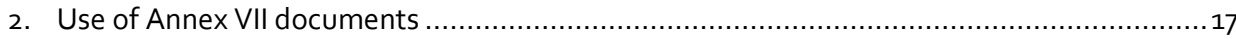

2.1 Selection of the companies ........................................................................ 17

2.2 Analysis of the Annex VII documents ...........................................................

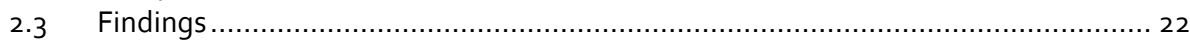

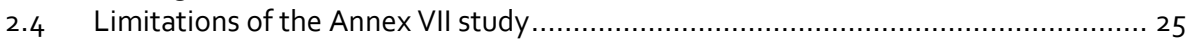

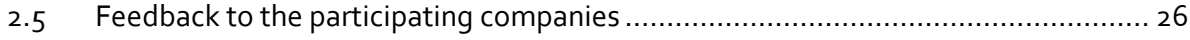

3. The results of the Web-based survey, for a company perspective .................................. 29

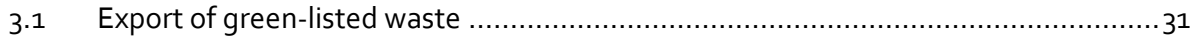

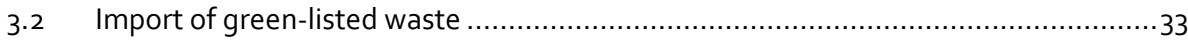

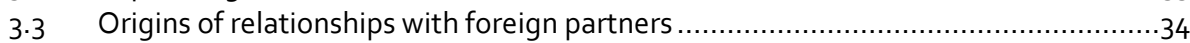

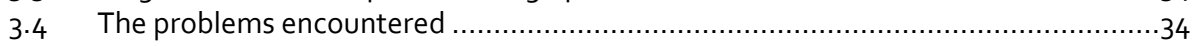

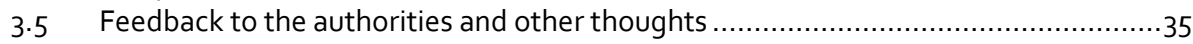

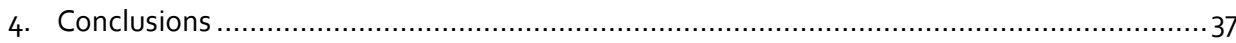

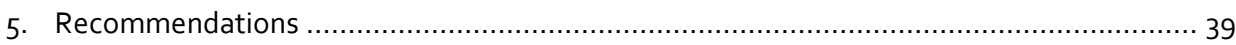

5.1 Recommendation 1: More guidance should be given on green-listed

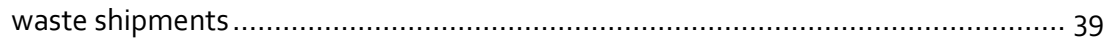

5.2 Recommendation 2: The reporting on green-listed waste shipments should

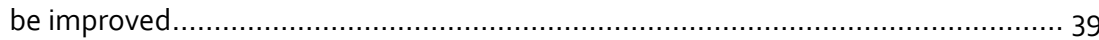

5.3 Recommendation 3: Inspection plans should cover shipments of green-listed waste .......................................................................... 40

5.4 Recommendation 4: Questionable shipments of green-listed waste should somehow be addressed.............................................................. 40

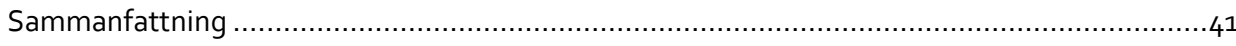

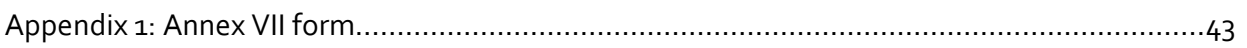





\section{Abbreviations}

- EEA: European Economic Area.

- EPA: Environmental Protection Agency.

- EU: European Union.

- EWC: European Waste Catalogue.

- NEA: Norwegian Environment Agency.

- OECD: Organisation for Economic Co-operation and Development.

- SYKE: Finnish Environment Institute.

- WSR: Waste Shipment Regulation (Regulation (EC) No 1013/2006 of the European Parliament and of the Council of 14 June 2006 on shipments of waste). 



\section{Summary}

The project was carried out to provide a better picture of transboundary shipments of green-listed waste involving project countries Denmark, Finland, Norway, and Sweden. Cross-border shipping of green-listed waste (i.e., waste listed in Annex III, IIIA, or IIIB of the Waste Shipment Regulation) for recovery can in most cases take place legally without the need for waste-shipment notification. These shipments are generally not controlled in the project countries but do have to be accompanied by an Annex VII form. In addition, according to Article 18 of the WSR, the person who arranges shipment must have a valid contract with the consignee before shipment may take place.

It was impossible to gain a complete picture of waste streams to and from the project countries, since not all of the countries have the relevant data readily available. Export data for 2014 from Denmark and Finland were available. Denmark's exports of greenlisted waste beyond the EU consisted mainly of metals $(475,263 t)$, alongside some cable $\operatorname{scrap}(4,313 t)$, plastics $(777 t)$, and tyres (913t). Finland exported at least 18,333 tonnes of metals and 4,202 tonnes of plastics out of the EEA (the reporting of waste-export data in Finland is not comprehensive). In Sweden, waste exports are not reported on, and reported figures were not yet available in Norway at the time of our study.

The primary effort in the project was devoted to an Annex VII inspection, which was carried out as a desk study. All told, 33 companies were asked to send all their Annex VIls and related contracts from September-October 2015 to the competent authority of their country. Special focus was given to companies exporting waste beyond the EEA, as were the waste streams consisting of metal scrap, plastics, paper, and cable waste. The team selected 434 Annex VII forms for detailed analysis, such that in cases of repeated similar shipments with similar Annex VIls only one form was selected. Of the documents chosen, 81 pertained to shipment out of the EEA. It was disturbingly common that the competent authorities' query did not elicit contracts related to the shipments described in the Annex VII documents. Most of these shipments presumably took place without a valid contract, counter to Article 18 of the WSR. In 192 out of 434 cases, no contract whatsoever was produced, and in 64 cases the contract was signed after the shipment had taken place. It was also very common that the Annex VII document was not properly filled in: some information either was completely absent or contradicted other entries on the form. Lack of clarity as to, for example, the waste type or the waste's final destination was considered a major error. In only 28 cases were the 
Annex VII completely filled in and the related contract provided (and valid at the time of shipment). It should be emphasised, however, that, because of the way in which the companies were selected and the Annex VIIs chosen for further analysis, any conclusion on the proportion of Annex VIIs in the project countries that were/are incomplete cannot be drawn, nor was such a conclusion the objective for the inspection. After the analysis, the competent authorities gave feedback to those companies whose Annex VIIs or contracts manifested errors, and some companies were even fined.

In addition to the Annex VII inspection, an important part of the project was our Web-based survey to ascertain how companies arrange shipments of green-listed waste. There were 21 replies from companies exporting or importing waste. Most of the companies seemed to be very careful to follow the regulations and know about their foreign customers, but, regrettably, some exporters are not always sure where their waste ultimately ends up.

The project made the competent authorities in the project countries more aware of how shipments of green-listed waste are organised and how the companies involved use Annex VII documents. Based on the findings from the project, four recommendations have been presented for the project countries to take into account when planning further actions:

- More guidance should be given on green-listed waste shipments.

- The reporting on green-listed waste shipments should be improved.

- Inspection plans should cover shipments of green-listed waste.

- Questionable shipments of green-listed waste should somehow be addressed. 


\section{Introduction}

\section{The Waste Shipment Regulation and green-listed waste shipments}

Transboundary shipments of waste are regulated by Regulation (EC) 1013/2006, on waste shipments, commonly known as the Waste Shipment Regulation (WSR). The WSR has been incorporated into the EEA Agreement, so it is followed also in Norway. The WSR specifies two procedures for transboundary shipments of waste: the notification procedure, wherein written consent from the competent authorities is required, and a lighter procedure, in which the shipments in question are accompanied by the socalled Annex VII document and the person arranging the shipment and the consignee have established a contract in accordance with Article 18 of the WSR.

Green-listed waste is defined as such waste as does not pose any likely risk to the environment when shipped for recovery and as, secondly, is listed in Annex III, IIIA, or IIIB of the WSR - for example, paper waste, plastic waste, untreated wood waste, and scrap metal. When green-listed waste is shipped between OECD and/or EU countries for recovery, the lighter procedure may be applied in most cases. The lightweight procedure is applicable also when waste listed in Annex III or IIIA is shipped for recovery to a non-OECD country that has made a reply to the Commission in respect of the WSR and has approved the lighter procedure for the waste type in question. The main category of cases wherein the notification procedure is followed involves shipment of hazardous or non-listed waste and shipping of any kind of waste for disposal. Also, when green-listed waste is shipped to a non-OECD country for recovery, the notification procedure is required if the importing country has not replied to the Commission in this connection or if it has responded that it requires a notification. Whether an importing country allows the import of certain green-listed waste with an Annex VII document or instead requires a notification can be checked in Regulation (EC) 1418/2007, on shipment of green waste into non-OECD countries (it is important to note that the description given here for the procedures applied is a general simplification covering the most common situations only - one should consult the WSR for more details when needed).

It should be noted that not all waste shipments are legally permissible under one of the two above-mentioned procedures. Shipments of hazardous waste from EEA to non-OECD countries are prohibited, as are shipments of green-listed waste to countries 
that have prohibited the import of the waste in question. These bans are listed in Regulation (EC) 1418/2007.

Waste shipments with accompanying notification are considered to be very well controlled: Competent authorities in the countries of dispatch, transit, and destination check the notification and give their consent to the shipments before they may proceed. Also, the authorities are given advance notification of each individual shipment at least three working days before shipment takes place, and certificates of receiving and of treating the waste are required. An original movement document (Annex IB) and copies of the written permits from the competent authorities should accompany a shipment subject to the notification procedure.

With regard to shipments of green-listed waste, the WSR does not impose any requirements to notify the competent authorities of shipments. It is required only that information in accordance with Annex VII of the WSR accompanies the waste and that the person arranging the shipment and the consignee have a valid contract under Article 18 of the WSR before shipment begins. Individual Member States may require the information specified in Annex VII for inspection, enforcement, planning, and statistical purposes, according to Article 18. Some Member States (for instance, Estonia and Hungary) even require sending copies of all Annex VII documents to the competent authorities, but the countries considered in this project-Denmark, Finland, Norway, and Sweden - do not. Because the companies arrange the shipments between themselves and the authorities are not automatically involved, it can be stated that the control of shipments of green-listed waste is not very strict. On account of this low level of control, the fact that interpreting the regulations requires some experience, and the fact that several kinds of operators are active in the waste business, there is a risk that not all shipments described as shipments of green-listed waste take place "by the book". It might be that some waste requiring a notification is shipped as green-listed or that waste is shipped in contravention of an export ban. Also, the information accompanying the shipment may not always be complete.

\section{The project}

This project reported upon here was carried out to gain better understanding of shipments of green-listed waste involving Denmark, Finland, Norway, and Sweden. Exports from these countries to non-OECD states were of particular interest. The work was focused in part on four selected waste streams: paper, plastics, metals, and cable waste. The main aims for the project were to get a picture of how the shipments are arranged and of how Article 18 of the WSR is followed (how Annex VII documents are used in 
practice, the quality of the data supplied therein, and whether the companies have valid contracts in place). It should be noted that, because the project was carried out as a desk study, such illegal shipments as sending of hazardous or non-listed waste as green-listed, of green-listed waste without an Annex VII document, and of green-listed waste by someone who is not allowed to arrange them (such as those conducting illegal operations or a person not falling under the jurisdiction of the country of dispatch) could not be addressed extensively by this project.

The project was funded by the Waste Group under the auspices of the Nordic Council of Ministers, and the TFS (Trans-frontier Waste Shipments) subgroup members from Denmark, Finland, Norway, and Sweden acted as the project team. The Finnish Environment Institute (SYKE) was responsible for co-ordinating the work. 



\section{Country-specific information on shipments of green-listed waste}

This section of the report describes the roles of the various authorities in each participating country, along with what is known about shipments of green-listed waste from the project countries. It was clear from the outset that gaining a comprehensive picture of all aspects of the various streams of green-listed waste would be impossible within the confines of the project, so only the readily available information is presented here.

\subsection{The authorities in the project countries and their duties re- lated to green-listed waste shipments}

\subsubsection{Denmark}

In Denmark, the Danish Environmental Protection Agency (Miljøstyrelsen) is the competent authority in the meaning of Article 2(18) of the WSR. Shipments of waste are controlled by this agency in co-operation with the Danish National Police (Heavy Vehicle Control), the municipalities, and the Danish Customs and Tax Administration (SKAT). Shipments of green-listed waste are controlled by means of spot checks in the same manner as waste subject to notification. Also, Miljøstyrelsen maintains an electronic system (Affaldsdatasystemet) to which companies are to report their waste exports and imports once a year.

\subsubsection{Finland}

The Finnish Environment Institute (Suomen ympäristökeskus, or SYKE) is the competent authority in Finland as defined in Article 2(18) of the WSR. According to the Finnish Waste Act (646/2011), SYKE shall supervise compliance with provisions pertaining to transboundary shipments of waste, and Finnish Customs oversees transboundary waste shipments in co-operation with SYKE. Shipments of green-listed waste are controlled at the borders and afterwards with the aid of data reported and maintained in the environmental administration's compliance-monitoring system, called Vahti. 


\subsubsection{Norway}

In respect of Article 2(18) of the WSR, the Norwegian Environment Agency (Miljødirektoratet, or NEA) is the competent authority in Norway. Miljødirektoratet controls shipments of waste jointly with customs authorities. There are no ordinary controls on green-listed waste, but these waste shipments are checked during spotcheck inspections at the border. All waste shipments crossing the Norwegian border are to be declared to Norwegian Customs.

\subsubsection{Sweden}

In Sweden, it is the Swedish Environmental Protection Agency (Naturvårdsverket) that is the competent authority as defined in Article 2(18) of the WSR. County administrative boards (Länsstyrelsen) supervise and control trans-boundary shipments of waste in co-operation with Swedish Customs, the police force, and the Coast Guard. Naturvårdsverket guides them and collaborates with them. When illegal shipments of waste are stopped, Naturvårdsverket is involved in deciding about their return. This authority does not inspect the shipments themselves; it controls documents and photos and acts in a guiding role.

\subsection{Information about shipments of green-listed waste in 2014}

For a better understanding of the waste streams and volumes, it was necessary to consider the types and quantities of data on green-listed waste shipments available in the project countries. Because the aim was not to estimate those waste streams, only the readily available data are presented here. Again, it was known from the beginning that obtaining a complete picture of the streams and volumes would be impossible and that even the official figures do not offer full coverage. Because the reporting period is typically one year and the project started in 2015, we chose the 2014 data for study. A summary of the data received from the project countries for 2014 is provided below.

\subsubsection{Denmark}

In Denmark, waste-treatment plants and collectors, producers, exporters, and importers of waste must submit annual reports to the waste-data system (the above-mentioned Affaldsdatasystemet maintained by Miljøstyrelsen) by 31 January of the following year. Because reporting is compulsory, it can be assumed that the data's coverage is comprehensive and that omissions are associated mainly with illegally shipped waste. 
Table 1 presents the amount of waste exported outside the EU from Denmark that was reported as green-listed in 2014 and the main countries of destination. Most of the green-listed waste listed in the table is in the categories selected for this project, with metals being the main stream. Paper waste was not exported beyond the EU. In all, 12 companies reported export of green-listed waste out of the EU in 2014 .

Table 1: Reported green-listed waste exported from Denmark beyond the EU in 2014, based on data from the Affaldsdatasystemet

\begin{tabular}{lrl} 
Plastics & 777 & Hong Kong, India, United Arab Emirates \\
Metals & 475,263 & China, India, Turkey \\
Cable scrap & 4313 & China, Hong Kong, Pakistan \\
Others (tyres) & 913 & Guinea, Nigeria \\
Total: & 481,266 & \\
\hline
\end{tabular}

\subsubsection{Finland}

In Finland, amounts of both notification-subject and green-listed shipments are reported yearly by the exporting companies, and supervising environmental authorities approve the reports. The reported data are maintained in the environmental administration's Vahti compliance-monitoring system. Regrettably, it is not comprehensive, because not all companies exporting waste are obliged to make Vahti reports. This effect is especially strong for relatively small companies, for which permission and supervision are handled by municipal environmental authorities. Amounts of waste exported from Finland as green-listed waste in 2014 and reported upon are presented below, in Table 2, along with the main import countries. It should be noted that the data were extracted manually from all waste exports, as the system does not classify waste as shipped under a notification or with an Annex VII document. Grouping of the exports by waste type too was performed outside the system, on the basis of waste descriptions and EWC codes. Most of the greenlisted waste exported falls under the project's selected waste streams, with metals and paper being the main streams. As in Denmark, paper waste was not sent beyond the EU. The 2014 Vahti data include exports of green-listed waste from 75 facilities, 12 of which reported export out of the EEA. Exports not covered by Vahti have not been estimated. 


\begin{tabular}{|c|c|c|c|c|c|}
\hline Waste type & $\begin{array}{r}\text { Export to EEA } \\
\text { countries }(t)\end{array}$ & $\begin{array}{r}\text { Export out of } \\
\text { the EEA (t) }\end{array}$ & Total (t) & $\begin{array}{l}\text { Main countries of des- } \\
\text { tination in the EEA }\end{array}$ & $\begin{array}{l}\text { Main countries of desti- } \\
\text { nation outside the EEA }\end{array}$ \\
\hline Paper and cardboard & 66,639 & 0 & 66,639 & $\begin{array}{l}\text { Germany, Poland, } \\
\text { Sweden }\end{array}$ & - \\
\hline Plastics & 9,450 & 4,202 & 13,652 & $\begin{array}{l}\text { Estonia, Latvia, } \\
\text { Sweden }\end{array}$ & China, Hong Kong, USA \\
\hline Metals & 65,281 & 18,333 & 83,614 & $\begin{array}{l}\text { Estonia, Portugal, } \\
\text { Spain }\end{array}$ & China, Hong Kong, India \\
\hline WEEE-related waste & 1,664 & 0 & 1,664 & $\begin{array}{l}\text { Estonia, Germany, } \\
\text { Sweden }\end{array}$ & - \\
\hline Cable scrap & 13 & o & 13 & Sweden & - \\
\hline $\begin{array}{l}\text { Others (for example, } \\
\text { ashes, slag, and catalysts) }\end{array}$ & 34,672 & 0 & 34,672 & $\begin{array}{l}\text { Germany, Norway, } \\
\text { Sweden }\end{array}$ & - \\
\hline Total: & 177,720 & 22,535 & 200,255 & & \\
\hline
\end{tabular}

\subsubsection{Norway}

In Norway, customs rules oblige companies to declare all waste shipments (including green-listed waste shipments) crossing Norwegian borders since July 2014, and the associated data should have been obtainable via Norwegian Customs. However, there had been problems in implementation of the new system, and no data for shipments of green-listed waste in $\mathbf{2 0 1 4}$ were available at the time of the study.

At the time of writing, it has become evident that the situation has already improved, and statistics are available for green-listed waste exports from Norway in 2015.

\subsubsection{Sweden}

In Sweden, companies are not obliged to report their shipments of green-listed waste, and related customs data are not readily available. No studies examining these exports exist either. Therefore, we do not have any estimates for Swedish greenlisted waste exports. 


\section{Use of Annex VII documents}

To ascertain how companies use Annex VII documents and whether they have valid contracts under Article 18 of the WSR, a joint inspection of the documents was carried out in late 2015. Competent authorities in each project country selected a few companies, who were asked to send copies of all Annex VII documents and related contracts corresponding to shipments from or to their facilities in September-October 2015. The target was 100-150 Annex VIls per country, but some countries provided many more. Accordingly, we had to limit the number of Annex VIls that were analysed in detail. This section of the report presents the process followed and the findings from this inspection.

\subsection{Selection of the companies}

As the main interest lay in exports, such companies were selected as were known to act as "persons arranging the shipment". In line with the scope of the project, the project team sought also to select companies exporting to non-OECD countries and exporting the waste types emphasised in the project (metals, paper, plastic, and cable waste). Other criteria entailed inclusion of both large and smaller companies and encompassing some companies that had had problems with WSR compliance and/or had previously been given guidance by the competent authority.

Most of the companies responded to the authority's request on time. Some replied that there had been no relevant shipments during the time in question, and one company in Finland even indicated that they were no longer involved in the waste business. One company did not respond to the request at all. Table 3 presents the numbers of companies requested to send documents and the results of the requests.

Table 3: Companies selected for the Annex VII inspection and the results of the requests

\begin{tabular}{l|r|r|r|r}
\hline Country & $\begin{array}{r}\text { Total number of } \\
\text { companies se- } \\
\text { lected }\end{array}$ & $\begin{array}{r}\text { Number of companies } \\
\text { whose documents were } \\
\text { checked }\end{array}$ & $\begin{array}{r}\text { The number with no } \\
\text { shipments in Septem- } \\
\text { ber-October 2015 }\end{array}$ & $\begin{array}{r}\text { The number of compa- } \\
\text { nies who did not respond }\end{array}$ \\
\hline Denmark & 12 & 6 & 6 & 0 \\
Finland & 10 & 6 & 3 & 1 \\
Norway & 7 & 7 & 0 & 0 \\
Sweden & 4 & 4 & 0 & 0 \\
\hline
\end{tabular}




\subsection{Analysis of the Annex VII documents}

Each Annex VII document was skimmed, and a smaller set of documents was selected for further analysis. As the quantity of documents supplied was huge, not every Annex VII for frequently repeated similar shipments was selected for in-depth analysis. When there was a series of Annex VIIs referring to the same companies (i.e., the person arranging the shipment, waste generator, consignee, and recovery facility), waste type (by description and waste codes), and recovery operation, only one of these documents was included; however, if several ways of filling in the document incompletely or otherwise incorrectly were detected in such a series, more than one document was selected.

The team's analysis of an Annex VII document consisted of five steps, each involving its own questions:

- Is there a contract connected to the shipment? Is it valid?

- Which stage of shipment does the Annex VII document correspond to? Is this the version of the document that the sender provides to the first carrier (referred to as "type $A$ " in this report), the version signed by the consignee (referred to as "type $\mathrm{B}^{\prime \prime}$ ), or that signed by the recovery facility (referred to as "type $C^{\prime \prime}$ ) when the waste has been received?

- Is each block that should be filled in for a document of this type properly completed?

- Does the document raise any other concerns? For example, is the destination for the waste unclear, or does it seem that Regulation 1418/2007 and/or the WSR has not been followed?

- What is the basic information from the Annex VII, and what observations were made in steps 1-4? (These were noted in an Excel table).

The deficiencies and errors observed in the documents were grouped into three categories. Minor errors often seem to arise from carelessness and, while they are indeed errors, were not considered very serious by the project team. These errors, especially when a document contained no more than one of them, did not lead us to assume that the rules and regulations had been disregarded, even though the associated shipments might in some cases be considered technically illegal under Article 2(35)g)iii) of the WSR. Major errors too may stem from carelessness, but these errors were considered more serious: some essential information on the shipment was missing or clearly declared incorrectly, or the document contained conflicting information. Some major errors gave the impression that the person arranging the shipment was unaware of the requirements or did not care about them. Finally, extremely serious errors are still more 
serious. They indicate that serious violations of the WSR might have occurred, though in most cases this could not be determined from the documents alone, without consulting the person who arranged the shipment. The types of deficiencies/errors in each category are presented in Table 4 .

Table 4: Deficiencies/errors observed in the analysis of Annex VII documents (and related contracts)

\begin{tabular}{|c|c|c|}
\hline Minor errors & Major errors & Extremely serious errors \\
\hline Quantity missing (in block 3 ) & $\begin{array}{l}\text { Person who arranged the shipment } \\
\text { (identified in block 1) not under the } \\
\text { jurisdiction of the country of dispatch }\end{array}$ & $\begin{array}{l}\text { No contract in accordance with Arti- } \\
\text { cle } 18 \text { of the WSR }\end{array}$ \\
\hline $\begin{array}{l}\text { Date of shipment missing or clearly } \\
\text { wrong (in block 4) }\end{array}$ & $\begin{array}{l}\text { Consignee and recovery facility in dif- } \\
\text { ferent countries }\end{array}$ & $\begin{array}{l}\text { The presented contract being signed } \\
\text { after the date of shipment }\end{array}$ \\
\hline $\begin{array}{l}\text { Carrier info missing or by no means } \\
\text { complete }\end{array}$ & $\begin{array}{l}\text { Information about recovery facility } \\
\text { missing, far from complete, or clearly } \\
\text { wrong (for example, an address that } \\
\text { is not a location of a recovery facility) }\end{array}$ & $\begin{array}{l}\text { The waste in question not being } \\
\text { green-listed }\end{array}$ \\
\hline $\begin{array}{l}\text { Carrier signature missing (relevant } \\
\text { only in cases of type B and C Annex } \\
\text { VIIs) }\end{array}$ & $\begin{array}{l}\mathrm{R} \text { code in block } 8 \text { missing or clearly } \\
\text { wrong }\end{array}$ & The shipment requiring a notification \\
\hline $\begin{array}{l}\text { Country information in block } 11 \text { in- } \\
\text { complete (typically, transit country or } \\
\text { countries not indicated) }\end{array}$ & $\begin{array}{l}\text { Waste description in block } 9 \text { missing } \\
\text { or inconsistent with the codes in } \\
\text { block } 10\end{array}$ & $\begin{array}{l}\text { The importing country having banned } \\
\text { import of the waste in question }\end{array}$ \\
\hline $\begin{array}{l}\text { Date of declaration in block } 12 \text { miss- } \\
\text { ing or clearly wrong }\end{array}$ & $\begin{array}{l}\text { Waste code(s) in block } 10 \text { missing or } \\
\text { contradictory }\end{array}$ & \\
\hline $\begin{array}{l}\text { Date in block } 13 \text { or } 14 \text { missing (rele- } \\
\text { vant only in cases of type B and C An- } \\
\text { nex VIIs) }\end{array}$ & $\begin{array}{l}\text { Country information in block } 11 \text { in- } \\
\text { consistent with the address in block } 6 \\
\text { or } 7\end{array}$ & \\
\hline Other relatively minor errors & $\begin{array}{l}\text { Signature in block } 12 \text { missing or } \\
\text { something wrong with this signature }\end{array}$ & \\
\hline & $\begin{array}{l}\text { Signature missing from block } 13 \text { or } 14 \\
\text { or something wrong with this signa- } \\
\text { ture (relevant only in cases of type B } \\
\text { and C Annex VIIs) }\end{array}$ & \\
\hline & Other relatively noteworthy errors & \\
\hline
\end{tabular}

Because the amount of missing or inconsistent information in the Annex VII documents was larger than expected, the smallest deficiencies were not recorded. Among these were the following: 
- A missing tick mark in the recovery facility box in block 7 or 14 .

- The quantity not being indicated in block 14 (type C Annex VII only).

- The carrier information being slightly incomplete (for example, the contact person or means of transport not being noted when this information was otherwise obvious).

- Use of Basel Convention code B1110 in block 10 in addition to OECD code GCo2o (even when the destination was in the EU).

- Use of an Annex IIIA waste code in block 10(i) instead of 10(iii).

- Incomplete contact information being supplied in block 1, 2, 6, or 7 if the same company was referred to with complete contact information in another block.

- The country not being stated in the address in block 1, 2, 6, or 7, if there was no doubt about it.

- The contact person not being indicated in block 2,6, or 7, so long as a phone number and/or e-mail address was provided.

- Dates being in a format other than dd.mm.yy, if they were still understandable.

- Use of an Annex VII version other than the latest one.

On account of the scope and nature of the study, it was not possible to check the following issues:

- Whether the national waste codes, which were sometimes provided in block 10(vi), were correct.

- The quality and accuracy of the quantity information in block 3 (for example, sometimes the amount may have been expressed in kilograms rather than, as it should be, in tonnes).

- Who signed block 12 (the person who arranged the shipment should sign this block, but in most cases it was impossible to verify whether this was done in reality).

- Whether the carriers were registered as waste carriers in their home country.

There were deemed to be errors related to these issues only if it was obvious that the Annex VII document was signed by a representative of the wrong company or gave incorrect quantity information.

Contracts were analysed at a cursory level only. Primarily, we checked that there was a contract matching the Annex VII (i.e., that the person arranging the shipment, 
consignee, and waste codes were the same), that the contract was signed and valid when the shipment took place, and that it seemed to be a contract in the meaning of Article 18 of the WSR (rather than something else, such as a commercial contract not covering the obligations under Article 18). As several distinct contract models had been used, it was not checked that each contract completely fulfilled the requirements of Article 18. It was assumed that the contracts are based primarily on the models provided by competent authorities. However, if clear mistakes in contracts were discovered, they were noted.

In all, 434 Annex VII documents were examined in detail. Of these, 359 were of type $A, 23$ of type $B$, and 50 of type $C$. The remaining two documents were either type $B$ or type $C$, but it was not possible to determine which. The basic information for the Annex VIls analysed is presented in tables 5 and 6 .

Table 5: The number of Annex VII documents analysed, by countries of dispatch and destination

\begin{tabular}{lccrrr} 
& $\begin{array}{r}\text { Nordic } \\
\text { countries }\end{array}$ & $\begin{array}{r}\text { Other EU } \\
\text { countries }\end{array}$ & $\begin{array}{r}\text { Other OECD } \\
\text { countries }\end{array}$ & $\begin{array}{r}\text { Other Asian } \\
\text { countries }\end{array}$ & Total \\
Export from Nordic countries (to countries in the first row) & & & & & \\
Denmark & 5 & 55 & 0 & 5 & 65 \\
Finland & 18 & 17 & 0 & 43 & 78 \\
Norway & 74 & 64 & 4 & 29 & 171 \\
Sweden & 8 & 97 & 0 & 0 & 105 \\
Total: & 105 & 233 & 4 & 77 & 419 \\
Import to Nordic countries (from countries in the first row) & & & & & \\
Denmark & 0 & 0 & 0 & 0 & 0 \\
Finland & 9 & 6 & 0 & 0 & 15 \\
Norway & 1 & 0 & 0 & 0 & 1 \\
Sweden & 95 & 9 & 0 & 0 & 104 \\
Total: & 105 & 15 & 0 & 0 & 120 \\
\hline
\end{tabular}


Table 6: The number of Annex VII documents analysed, by waste type

\begin{tabular}{|c|c|c|c|c|c|c|}
\hline $\begin{array}{l}\text { Origin and desti- } \\
\text { nation country }\end{array}$ & $\begin{array}{r}\text { Metals } \\
\text { (B1010, B1020, } \\
\text { B1031, B1050, B1100, } \\
\text { GC010, GC020, and } \\
\text { GBo40) }\end{array}$ & $\begin{array}{l}\text { Plastics } \\
\text { (B3010) }\end{array}$ & $\begin{array}{r}\text { Paper } \\
\left(\text { B3020) }^{2}\right.\end{array}$ & $\begin{array}{r}\text { Cable waste } \\
\text { (B1115) }\end{array}$ & $\begin{array}{r}\text { Other waste or unclear } \\
\text { waste type } \\
\text { (B1130, B2040, B3080, } \\
\text { B3140, and BEU05) }\end{array}$ & Total: \\
\hline Nordic to Nordic & 52 & 8 & 36 & 0 & 9 & 105 \\
\hline Nordic to EU & 50 & 93 & 79 & 5 & 6 & 233 \\
\hline EU to Nordic & 13 & 1 & 1 & 0 & o & 15 \\
\hline Nordic to OECD & 0 & 0 & 3 & 0 & 1 & 4 \\
\hline Nordic to Asian & 52 & 13 & 10 & 2 & 0 & 77 \\
\hline Total: & 167 & 115 & 129 & 7 & 16 & 434 \\
\hline
\end{tabular}

\subsection{Findings}

Most of the Annex VII documents examined were incomplete, and it was common for there to be no contract. In 192 cases, the competent authority had not received any contract related to the shipment, and one can assume that the companies did not send the contracts because they did not exist. Only two companies stated that the contracts were in place but, because of IT-related problems, they could not find all of them. In 64 cases, the contract was signed after the actual date of shipment, most commonly in November 2015 after receipt of a request from the competent authority. There were only 28 cases in which the Annex VII document was filled in properly and there was a contract related to the shipment that was valid during the shipment. A summary of the errors found in the course of the analysis is presented in Table 7, and this is expanded upon in the following paragraphs.

Table 7: A summary of the flaws in the cases analysed (Annex VIIs + contracts)

\begin{tabular}{|c|c|c|c|c|c|c|c|}
\hline \multirow{3}{*}{$\begin{array}{l}\text { Origin and } \\
\text { destination } \\
\text { country }\end{array}$} & \multicolumn{3}{|c|}{ Extremely serious errors } & \multirow{3}{*}{$\begin{array}{r}\text { Cases of } \\
\text { extremely } \\
\text { serious issues, } \\
\text { total }\end{array}$} & \multirow{3}{*}{$\begin{array}{r}\text { Major but } \\
\text { not } \\
\text { extremely } \\
\text { serious } \\
\text { errors }\end{array}$} & \multirow{3}{*}{$\begin{array}{r}\text { Minor } \\
\text { errors } \\
\text { only }\end{array}$} & \multirow{3}{*}{$\begin{array}{r}\text { No errors; } \\
\text { contract } \\
\text { OK }\end{array}$} \\
\hline & $\begin{array}{r}\text { Contract } \\
\text { absent }\end{array}$ & $\begin{array}{r}\text { Contract } \\
\text { signed after }\end{array}$ & $\begin{array}{r}\text { Other error } \\
\text { made }\end{array}$ & & & & \\
\hline & & shipment & & & & & \\
\hline
\end{tabular}

\begin{tabular}{|c|c|c|c|c|c|c|c|}
\hline Nordic to Nordic & 71 & 6 & 4 & 81 & 13 & 4 & 7 \\
\hline Nordic to EU & 78 & 51 & 1 & 129 & 63 & 24 & 17 \\
\hline EU to Nordic & 12 & 0 & 0 & 12 & 2 & 1 & o \\
\hline Nordic to OECD & 1 & 2 & 0 & 3 & 1 & 0 & o \\
\hline Nordic to Asian & 30 & 5 & 1 & 36 & 27 & 10 & 4 \\
\hline Total: & 192 & 64 & 6 & 261 & 106 & 39 & 28 \\
\hline
\end{tabular}




\subsubsection{Extremely serious errors detected}

In addition to the absence of a contract and signing of contracts after the actual date of shipment, there were six cases wherein the documents indicate that further violations of the WSR took place. One of these involved export of scrap to an Asian country in contravention of an import ban, in violation of Regulation 1418/2007. In one case, the classification as green-listed waste seemed to be incorrect in light of an accompanying document attached to the Annex VII form, wherein the details of the waste were specified. In this case, the importing country was in the EU. In the final four cases, shipments of non-listed waste from one project country to another should have entailed a notification. It should be noted that in these cases it is possible also that the classification as non-listed waste was incorrect. The competent authorities may have received further information from the companies later on, after requesting additional information. The results presented here, however, are based solely on the information given in the documents.

\subsubsection{Major errors detected}

In many cases, some blocks of the Annex VII document were not completed. Absence of information was considered a major error if that information was fundamental to the shipment. Examples are R codes; waste codes; waste descriptions; details of the recovery facility; and the signatures in blocks 12, 13, and 14. In addition to its incompleteness, inconsistency in the essential information was considered a major error.

Most of the major errors were related to missing, unclear, or contradictory information about the waste. In 20 documents, the description of the waste usually provided in block 9 was either absent or replaced with something that was not a description of the waste - a reference number or something else that cannot be considered a usual description. In 72 documents, there was a problem with the waste codes: either one or more waste codes were missing or there was a discrepancy between the waste description and waste codes or between the Basel Convention code and the EC list of waste codes (for instance, Basel code B3010, for solid plastic waste, combined with EC code 191202 , indicating ferrous metals).

In 54 documents, block 9 (for $R$ codes / D codes) was either left completely blank or lacked the numeric portion of the code; i.e., only "R" was stated. In addition, some documents displayed a clearly incorrect $\mathrm{R}$ code, as with the use of $\mathrm{R}_{4}$ (for recycling/reclaiming of metals and metal compounds) in the case of plastic waste. Additionally, a very common occurrence was the use of interim recovery code $\mathrm{R} 12$ or R 13 without any information about the non-interim operation. For shipment to interim operations, the competent authorities in the project countries generally require noting the non-interim code too in Annex VII, in the format "R12 followed by R4" (Denmark is still considering its 
stance on this issue, but for our study the absence of a non-interim recovery code was regarded as an error irrespective of the country of dispatch).

In 50 documents, the information about the consignee and/or recovery facility raised concern: Six documents had a block 7 (for the recovery facility) that had been left completely blank. In 15 documents, the consignee's address was in a different country than the recovery facility, which is not allowed - the consignee shall be under the jurisdiction of the country of destination. Several documents it appeared to state an address in block 7 that was not the location of the actual recovery facility but, for example, the address of the recovery company's city-centre headquarters. In some cases, not just the address was incorrect - the company that actually recovered the waste was not the company indicated in block 7 . This was revealed when exporting companies were later asked for clarification.

The requirement that the person who arranges the shipment be under the jurisdiction of the country of dispatch was not met in the case of six documents. In these cases, the consignee acted as the person arranging the shipment and hence had an address in a different country than the waste producer.

There were 19 documents in which the signature in block 12 was either missing or detected as belonging to some other party than the person who arranged the shipment. In some cases, it might be that the person who arranged the shipment archived a copy of the Annex VII document before signing it, but in the majority this was clearly not the explanation, given that the first carrier's signature was already present or the copy of the document was the recovery facility's version, with signatures in blocks 13 and 14 .

\subsubsection{Minor errors detected}

In the survey, some instances of empty blocks or unclear information were considered to constitute only a minor error. Among these are cases of missing or unclear dates in blocks 4, 12, 13, and 14; missing or largely incomplete carrier information in block 5 ; incomplete contact information in blocks 2, 6, and 7; absence of a signature on behalf of the carrier in block 5 (when the Annex VII document in question was the consignee's or recovery facility's version); and incomplete country information in block 11.

Incomplete carrier information was quite commonplace. There were 171 Annex VII documents wherein either the carrier information was missing or far from complete (for example, only the name of the company was mentioned) or it was unclear whether the missing piece of information was the identity of another carrier (typically a sea carrier) in block 5 or one or more transit country in block 11 . In a case of waste sent from Finland to Germany wherein only a road carrier's information was given, it is clear that a sea carrier or transit countries should have been mentioned - perhaps even both, if the 
route was via Estonia, Latvia, Lithuania, and Poland. It should be noted that the competent authorities in the project countries do differ in their views about sea carriers. If the waste remains in a lorry while at sea, Sweden and Norway deem the sea travel comparable to crossing a bridge and do not require information on the sea carrier in Annex VII, while Finland and Denmark require indicating the sea carrier in block 5 even in this case. These differences notwithstanding, there were few Annex VIIs in which an unclear combination of carrier and transit countries would have been the only error; hence, though stating a route that was unclear for reason of lack of mention of a sea carrier or transit countries was regarded as an error irrespective of the countries involved, divergences in interpretation among the competent authorities do not greatly affect the results of our survey. Finally, incomplete or missing country information in block 11 was quite frequent also when the carrier information was appropriately supplied.

Also, errors such as missing or unclear dates were numerous. In 46 documents, block 4, for the date of shipment, either was left blank or contradicted other dates in the document. The date of declaration in block 12 was absent or clearly wrong in 19 documents, and the date of receipt or recovery in block 13 or 14 was absent from eight documents. It was quite common for the dates of transfer to be missing from block 5 (carrier information), but this was not counted as a separate error; missing dates in block 5 were considered to be an aspect of incomplete carrier information.

Incomplete contact information for the companies specified in block 2, 6, and/or 7 was deemed a minor error too. Block 1 (for the person arranging the shipment) was filled in properly for the most part, but other blocks for company information were often incomplete. In most cases, the address was provided, while the name of the contact person, a phone and fax number, and an e-mail address were often omitted. The information was considered incomplete if neither a phone number nor an e-mail address was provided - the lack of a contact person's name and/or of a fax number was not deemed an error.

\subsection{Limitations of the Annex VII study}

It should be noted that ours was not a scientific study and the set of Annex VIls selected for detailed analysis was not a representative sample. On account of the way in which the companies were selected (with inclusion of companies that were assumed to have problems) and how Annex VII documents were selected for further analysis (with only one Annex VII document from a larger series being selected unless there were different mistakes), the set of documents analysed in detail displayed a greater than average 
concentration of documents from smaller companies (companies making fewer shipments) and of incomplete or otherwise worrying documents. Therefore, we cannot responsibly draw conclusions such as "x per cent of shipments of green-listed waste take place without a valid contract and/or with an incomplete Annex VII document" on the basis of this study.

However, since the cases wherein everything was fully correct were very few, this snapshot still provides reasonable evidence for the claim that problems exist in relation to green-listed waste shipments.

At the outset, concern was expressed that the project team might receive Annex VIls created after the fact for inspection purposes, rather than documents that had actually been used. However, the quality of the documents seems to indicate that this scenario did not materialise, at least on a large scale.

It should be borne in mind also that shipments without an accompanying Annex VII form could not be found and addressed within the scope of the study.

\subsection{Feedback to the participating companies}

In response to the findings from the Annex VII study, the competent authorities gave feedback to several of the companies. Some were asked for further clarification of their exports, and a few companies were even fined. Below, more detailed information is given in this connection, for each country.

\subsubsection{Denmark}

At the time of preparation of this report, Denmark's EPA had not yet contacted the companies whose Annex VII documents demonstrated problems. The authority will request clarification and provide further guidance in the near future.

\subsubsection{Finland}

Finland's SYKE, as the competent authority, contacted all six companies whose documents were inspected and gave them feedback on their Annex VIls. Four of the companies were asked for further clarification as to, for example, the waste types and the ultimate destination for the waste. At the time of reporting, two companies had provided further information, on the basis of which there was no reason to suspect serious offences. 


\subsubsection{Norway}

The NEA conducted follow-up with two companies that were suspected of involvement in illegal export, and it stopped further shipments of this waste. Five companies with no legal contracts in place were contacted too. The NEA did not find the offence serious enough to report it to the police or impose a fine, but the companies are going to be encompassed by next year's inspection plan. The most positive outcome of the project from the Norwegian standpoint is that all companies now report all green-listed waste exports to Norwegian Customs.

\subsubsection{Sweden}

The Annex VII documents of the four companies selected for in-depth examination were under the control of the Swedish Environmental Protection Agency. All of these companies had Annex VII documents that were incomplete and contained major errors. Each company was handed an environmental penalty, a fine in the amount of 10,000 SEK (approximately EUR 1,000). 



\section{The results of the Web-based sur- vey, for a company perspective}

In addition to the Annex VII inspection and the gathering of national statistics, the project included asking company representatives about their practices and opinions related to green-listed waste shipments, via a Web-based survey. The questionnaire used was created with the Webropol tool in four languages (Danish, Finnish, Norwegian, and Swedish), and companies from the project countries were asked to take part in the survey in February 2016. The request was sent to the companies whose Annex VIls were checked and also to a larger group, members of certain industry associations. In total, 22 responses were received, seven each from Norway and Sweden, five from Finland, and two from Denmark. One respondent was not based in a project country. The majority of the respondents were from waste treatment, waste trading, or metal-scrap recycling companies (a breakdown is provided in Figure 1). In all, 21 respondents stated that their work involves cross-border shipments of waste. Most of the companies the respondents represented were exporting waste or both exporting and importing it; see Figure 2 for the distribution. The following subsections present the most interesting findings from the survey. 
Figure 1: Respondents in the Web-based survey, by the area of company operations represented

\section{Number of respondents}
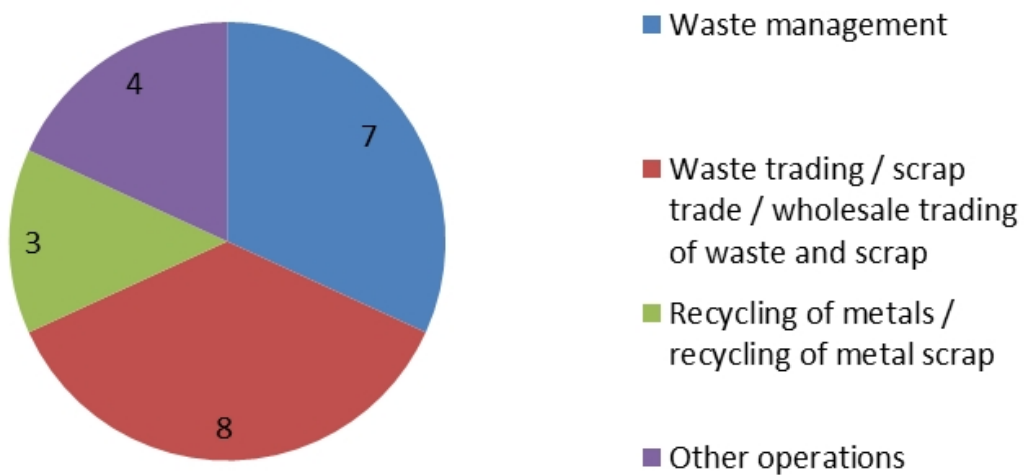

- Other operations

Figure 2: Respondents by the type of waste-shipment activity that their companies were performing

\section{Number of respondents}

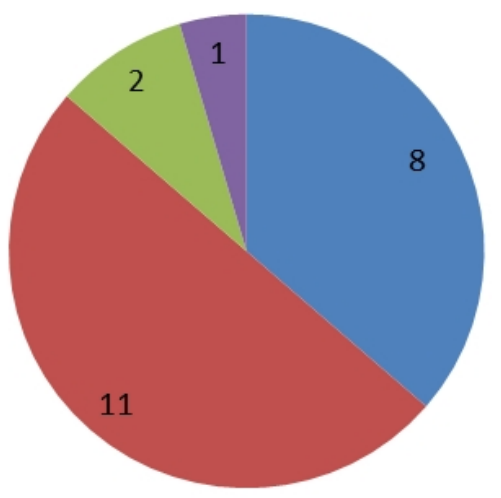

Export of waste

Export and import of waste

Import of waste

Neither export nor import 


\subsection{Export of green-listed waste}

Fifteen respondents represented companies that were exporting green-listed waste. The waste types mentioned most often among those they export are metals, plastic, and cables; see Figure 3. The most frequently mentioned destinations for green-listed waste were in EU or EFTA countries (15 replies) and in Asia (five replies).

Figure 3 : The types of green-listed waste exported by the 15 exporters of green-listed waste taking part in the Web-based survey

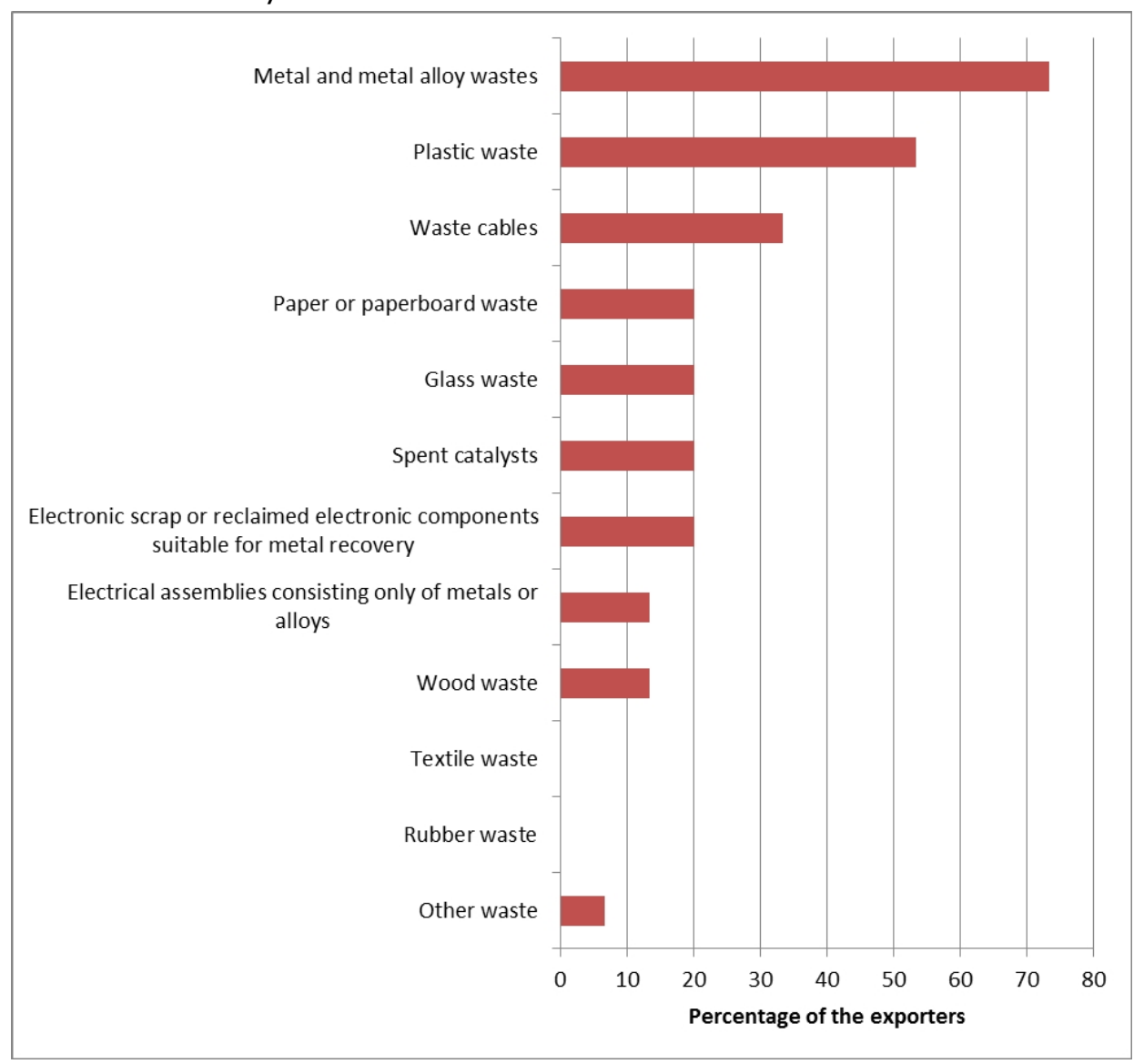


We asked how the companies determine whether export of a certain waste type to a certain country is allowed. Most of the respondents (11) stated that they refer to the WSR and related regulations for this purpose. One also separately mentioned Regulation 1418/2007. Quite a few rely on the competent authorities also - seven respondents stated that they use the Web site of the relevant competent authority, and six ask for advice. In a slightly disturbing result, two respondents admitted that they did not know, because the company has a long history of similar exports and someone else had previously dealt with this. It should be noted that import bans and other controls in third countries are subject to changes, and Regulation 1418/2007 is updated from time to time, so it is recommended to check the current situation regularly.

We also asked whether the exports are accompanied by an Annex VII document and whether the companies have valid contracts in line with Article 18 of the WSR. Thirteen respondents replied that they always use an Annex VII, while one respondent indicated that for exports to India a "Form 9 " document is used. One respondent stated that an Annex VII always accompanies road-based transport but they send it by e-mail in cases of shipment by sea. Eleven respondents responded that they have valid contracts with all companies they export to, three stated that they have contracts but were not sure whether these are contracts under Article 18. One respondent admitted that the company does not have valid contracts with all importing companies, offering the explanation that the consignee had not signed the contract yet.

In all, 12 exporting companies were acting as "person who arranges the shipment". The respondents representing these companies answered a question about their roles in these shipments. The distribution of the replies is presented in Figure 4: six identified their company as a licensed collector, five as a waste producer, and three as a new producer that carries out operations prior to shipment. In addition, there were two registered dealers, two registered brokers, and - surprisingly - three holders of waste. A holder of waste is permitted to act as the person who arranges the shipment only when all the other parties mentioned above are unknown or insolvent. The survey item did not state this or explain the term, so why these companies did not identify themselves as something other than holders remains unclear, as does whether they are not licensed or registered. 
Figure 4: The role of the 12 exporting companies in shipment of green-listed waste when they were acting as "person who arranges the shipment" (respondents could select multiple options if their role varied with the shipment)

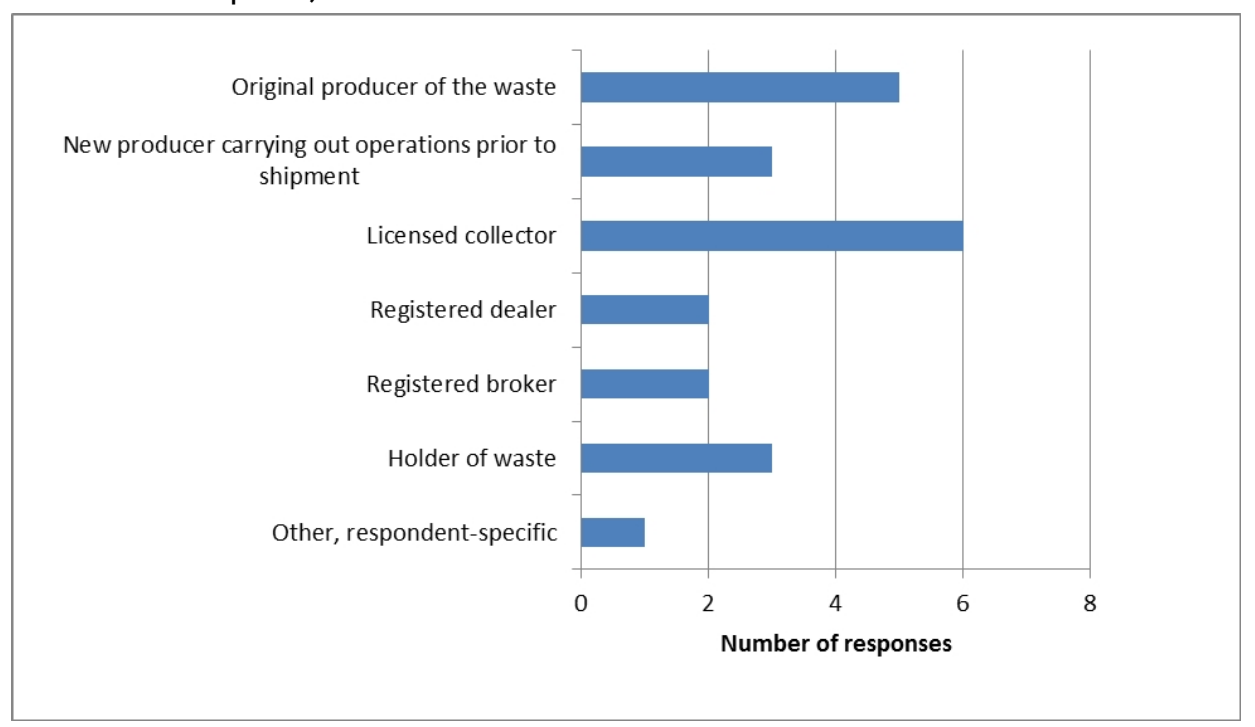

Furthermore, the exporting companies were asked about the roles of the receiving companies to which they were exporting at the time of the survey. Five companies were exporting green-listed waste to companies that do not treat the waste themselves but act as a broker or dealer. Only two respondents stated that they know where the broker or dealer is taking the waste in each individual shipment. Four replied that they know in general terms. The main reason cited for being unaware of the final destination was that the dealer or broker sends the waste to several facilities, so they do not know the details for each individual shipment. One respondent specified that the company knows that the consignee is allowed to receive the waste in question.

\subsection{Import of green-listed waste}

Nine respondents represented such companies as import green-listed waste. Eight stated that the imports always come with an Annex VII document, while the other admitted that sometimes this document is missing because either the customer has not provided it or the carrier has lost it. According to the responses, eight companies had valid contracts under Article 18 of the WSR with all foreign companies that send them greenlisted waste; one was not sure whether their contracts comply with Article 18. 


\subsection{Origins of relationships with foreign partners}

We asked how the companies find their foreign partners and how they arrive at a decision to co-operate with them. In all, 14 respondents answered these questions. According to the responses, 13 companies use their established contact networks to find foreign partners, and nine meet representatives of foreign companies at fairs, conferences, and other events. Eight respondents stated that companies abroad contact them. One respondent mentioned also that the sales department of the business group handles contacts with customers. Traders and agents were mentioned too. Two respondents stated that the company finds foreign partners on the Internet.

Most companies (12) check that the foreign entity has all the necessary licences before beginning to co-operate with them, and the majority of the respondents (10) stated that the partners have certificates or some other evidence of operating in an appropriate manner. Eight respondents stated that they consult other companies that have co-operated with the facility in question, and seven replied that they even au$\mathrm{dit} / \mathrm{visit}$ the facility. Five companies use price as a criterion, and simplicity of the logistics solution was separately mentioned by one respondent. One response indicated, further, that the company's customers belong to an international umbrella organisation that accepts only companies that have everything in order.

\subsection{The problems encountered}

We asked what kinds of problems the companies had faced with foreign companies when exporting green-listed waste. Fifteen respondents answered the question specifically about export to OECD countries. One of them stated that the company does not export to other OECD countries. Of the other respondents, nine indicated that the company had not had any problems, three cited problems with waste-shipment documents, and two mentioned having had problems related to classification of waste. Problems related to differences in legislation; to language barriers; and to differing interpretations of, for example, Annex VII requirements received one mention each. In more detailed description of the problems, two respondents mentioned that it is difficult to get the consignee to send back a signed copy of the Annex VII.

In all, 13 respondents answered the question on export to non-OECD countries. Three stated that they do not export to non-OECD countries. Six companies had not had any problems with companies outside the OECD, according to the respondents. Two referred to problems related to classification of waste, and two cited issues with 
waste-shipment documents. Receiving one mention each were problems with differences in legislation, environment- or health-related issues at the recovery facility, problems with authorities in the importing country, language barriers, and problems related to cultural differences.

\subsection{Feedback to the authorities and other thoughts}

In addition, companies were given an opportunity to send feedback to the competent authorities and freely share their thoughts about waste shipments, the WSR, and other waste-related matters. Most respondents (20) stated that they were happy with the guidance provided by these authorities; only two indicated that they were not. Twenty respondents indicated that they had been in contact with the competent authority of the country where they are based, mainly seeking advice on waste-shipment-related issues, and 10 respondents had participated in training on waste shipments organised by the national competent authority.

Five respondents gave feedback for the competent authorities. One expressed hopes of getting a response to a specific enquiry instead of general advice referring to legislation. One respondent thought that it would be good if Annex VII documents could be dealt with electronically. Electronic handling of documents was mentioned by another respondent too. Two respondents were of the opinion that more control is needed, to catch those who do not comply with requirements. They suggested requiring not only border controls but also controls on waste classification and facility visits by authorities, for purposes of getting an overview of the reality in which the companies and their competitors operate.

Six respondents shared further thoughts about waste shipments, the WSR, and other waste-related issues. One stated that the process is not easy, because there are many cross-references to lists and annexes and the waste codes are not always clear. Another respondent mentioned, in addition to this, that there are too many places one must check with respect to certain issues. One respondent provided feedback specifically related to waste-shipment notifications: greater flexibility for choosing an alternative border-crossing point was sought. Also, one respondent expressed a wish that the authorities would accept advance announcements of notified shipments by several means, not restricting the method to, for example, fax alone. This respondent hoped for more uniform interpretation of the WSR too, stating that some countries interpret the rules "as they wish". Finally, a respondent stated that it would be good to have a forum in which authorities and waste producers/carriers can meet and discuss problems and approaches. 



\section{Conclusions}

From the reported data for 2014 from Denmark and Finland, the Annex VII documents analysed in the project, and the online survey, it seems that the countries of destination for green-listed waste shipped out of the EU/EFTA from the project countries are mainly in Asia. China, Hong Kong, and India are among the typical destinations.

Although ours was not a scientific study and the Annex VII documents examined in the project do not form a representative sample, it can be stated that shipments of green-listed waste from/to the project countries do not always take place by the book. Annex VIls are often left incomplete or contain contradictory information, and contracts in the meaning of Article 18 of the WSR have not always been established before shipment begins. The reasons for the careless attitude to the requirements of Article 18 thereby demonstrated were not examined, but a low risk of getting inspected might be one of them.

It does appear that, even if the paperwork is not always completed with due care, many companies take shipments of green-listed waste as seriously as shipments that are subject to notification. These companies know where their waste ends up and how the recovery facilities operate. On the other hand, it is alarming that there are also many actors who are not always aware of the final destination of their waste.

In addition to making competent authorities in the project countries more aware of how Annex VII documents are used in shipments of green-listed waste, the project made a small contribution to better compliance with Article 18 of the WSR even before dissemination of the results. It is likely that several contracts that had not previously existed were established when the competent authorities requested these documents. After the analysis, several companies received feedback on their Annex VIls and missing contracts, which we hope will lead to establishment of applicable contracts in more cases and creation of more consistent and complete Annex VIls. 



\section{Recommendations}

Proceeding from the findings and conclusions emerging in the survey, the project team formulated four recommendations for the project countries to take into account when planning further actions. These recommendations, together with a brief explanation of the associated rationale, are presented below.

\subsection{Recommendation 1: More guidance should be given on green-listed waste shipments}

It was noted in the course of the study that the requirement to have an effective contract before the shipment starts is often ignored. In addition, Annex VII documents frequently are incomplete or contain contradictory information. Many companies dealing with shipments of green-listed waste are not involved in notified shipments or do not even perceive their operations as part of the waste business, which might render them less aware of the requirements of the WSR and leave them outside the target group for training events arranged by the competent authorities. Therefore, guidance and training especially tailored to companies involved in shipments of green-listed waste should be provided.

\subsection{Recommendation 2: The reporting on green-listed waste ship- ments should be improved}

At the moment, it remains very difficult to estimate green-listed waste flows from or to the project countries, since reports that are reliable in this respect are not available from some of the countries. In Denmark and Norway, all exporters and importers are obliged to report their shipments, but the Norwegian obligation is still quite new and some time might pass before it is fully adhered to. In Finland, the body of reported data does not cover all shipments of green-listed waste. Finally, Sweden imposes no obligation to report shipments of green-listed waste. Reported data would also provide information that is essential for planning of targeted inspections. 


\subsection{Recommendation 3: Inspection plans should cover shipments of green-listed waste}

Article 50 of the WSR obliges countries to establish one or more inspection plans by 1 January 2017. As green-listed shipments are generally not monitored yet can be problematic in several ways - for example, hazardous waste can be shipped as greenlisted, shipments may be arranged by persons who are ineligible to act as "person who arranges the shipment", and destinations for waste often remain unclear - it is recommended that green-listed shipments be included in the project countries' inspection plans.

\subsection{Recommendation 4: Questionable shipments of green-listed waste should somehow be addressed}

The survey could not practically explore cases wherein the person who arranges the shipment is not under the jurisdiction of the country of dispatch or is otherwise not eligible to act in the "person who arranges the shipment' role. Neither could the scope include shipments that take place without an Annex VII document. Example cases are shipments arranged by foreign companies or private persons and shipments of stolen scrap. Therefore, further consideration should be given to how shipments of these types could best be addressed. 


\section{Sammanfattning}

Det här projektet genomfördes för att få en bättre bild av gränsöverskridande transport av grönlistat avfall. Projektet innefattar projektländerna Danmark, Finland, Norge och Sverige. Gränsöverskridande transport av grönlistat avfall (avfall som beskrivs i Bilaga III, IIIA eller IIIB i Avfallstransportförordningen) för återvinning, kan i de flesta fall ske utan en anmälan om avfallstransport. Dessa transporter kontrolleras generellt inte i projektländerna, men ett formulär för Bilaga VII, måste bifogas. Därutöver ska person som arrangerar transporten enligt Artikel 18 i Avfallstransportförordningen ha ett giltigt avtal med mottagaren innan transporten kan ske.

Det är inte möjligt att ge en heltäckande bild av avfallsflödena till/från projektländerna, eftersom sådan data inte är lättillgänglig i alla projektländer. Exportdata från året 2014 från Danmark och Finland presenteras. Danmarks export av grönlistat avfall utanför EU bestod huvudsakligen av metaller, 475263 t och därutöver exporterades kabelskrot (4 313 t), plast (777 t) och däck (913 t). Finland exporterade åtminstone $18333 \mathrm{t}$ metaller och $4202 \mathrm{t}$ plast utanför EEA - data för avfallsexport som rapporterades i Finland är inte helt täckande. I Sverige rapporteras inte avfallsexporten och i Norge var den rapporterade datan inte tillgänglig ännu.

Det största utfallet av projektet var en inspektion av Bilaga VII, som genomfördes som en skrivbordsstudie. Sammanlagt ombads 33 företag skicka alla sina Bilaga VII:or och relaterade avtal från september-oktober 2015 till den ansvariga myndigheten i sina hemländer. Fokuset var särskilt på företag som exporterar avfall utanför EEA, samt även på avfallsflöden för metallskrot, plast, papper och kabelavfall. För detaljerad analys samlades 434 exemplar av Bilaga VII, så att endast ett exemplar av Bilaga VII valdes då liknande transporter upprepades med liknande Bilaga VII:or. I 81 fall gällde det transport utanför EEA. Det var oroväckande vanligt att de ansvariga myndigheterna inte mottog några avtal som anknöt till transporterna beskrivna i Bilaga VII. De flesta av dessa transporter har troligen skett utan giltigt kontrakt och de strider därmed mot Artikel $18 \mathrm{i}$ Avfallstransportförordningen. I 192 fall av 434 presenterades inget kontrakt alls och i 64 fall undertecknades kontraktet efter det att transporten hade skett. Det var också mycket vanligt att Bilaga VII inte var korrekt ifylld, utan att en del av informationen antingen saknades helt eller inte stämde med annan information. Otydligheter om till exempel avfallstypen eller om avfallets slutdestination betraktades som stora fel. Endast 28 fall var sådana där Bilaga VII var komplett ifylld och där det relaterade kontraktet, som var giltigt 
under transporten, också tillhandahölls. Det bör dock noteras att på grund av hur företagen valdes ut och hur Bilaga VII:orna valdes ut för vidare analys kunde det inte dras någon slutsats om en hur stor andel av ofullständigt ifyllda Bilaga VII:or det finns $i$ projektländerna, och det var inte heller syftet med inspektionen. Efter inspektionen gav de ansvariga myndigheterna feedback till företagen som hade oklarheter i sina Bilaga VII:or eller avtal och vissa av företagen blev till och med bötfällda.

Utöver inspektionen av Bilaga VII genomfördes en webbenkät i för att ta reda på hur företag arrangerar transporter av grönlistat avfall. Projektet mottog 21 svar från företag som exporterar eller importerar avfall. De flesta av företagen verkar vara mycket noggranna med att följa förordningarna och känna till sina utländska kunder, men dessvärre finns det några exportörer som inte alltid känner till vart deras avfall slutligen hamnar.

Projektet gav de ansvariga myndigheterna i projektländerna mer kunskap om hur transporter av grönlistat avfall organiseras och hur företagen använder Bilaga VII. Baserat på utfallet togs det fram fyra rekommendationer att beakta för projektländerna, när de planerar vidare åtgärder:

- Det behövs mer vägledning för transport av grönlistat avfall.

- Rapporteringen av transporter av grönlistat avfall bör förbättras.

- Transporter av grönlistat avfall bör inkluderas i inspektionsplanerna.

- Tvivelaktiga transporter av grönlistat avfall bör också i fortsättningen åtgärdas på något sätt. 


\section{Appendix 1: Annex VII form}

Figure 5: Information accompanying shipments of waste as referred to in article $3(2)$ and (4) - consignment information (1)

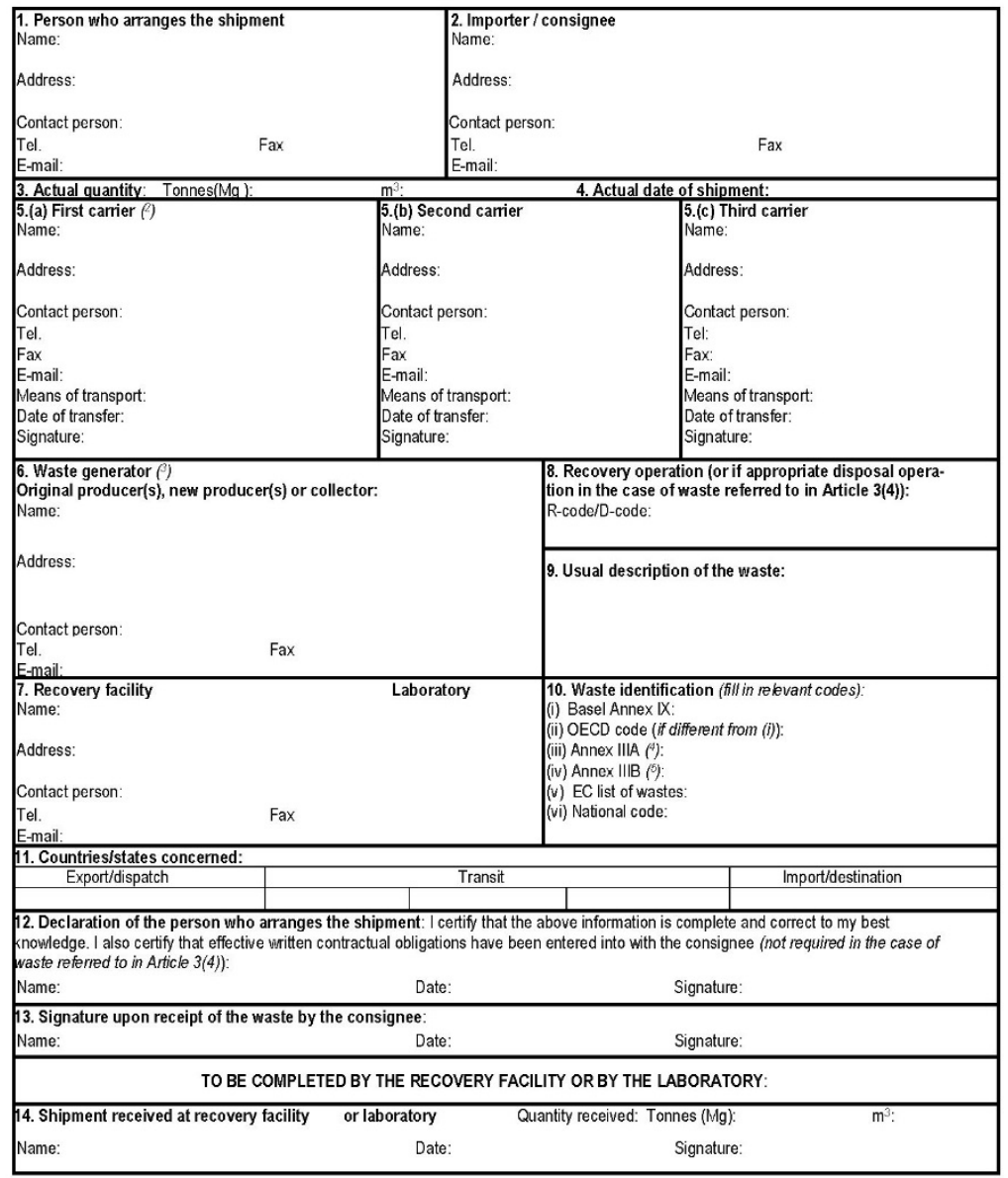

Note: ${ }^{1)}$ Information accompanying shipments of green listed waste and destined for recovery or waste destined for laboratory analysis pursuant to Regulation (EC) No. 1013/2006. For completing this document, see also the corresponding specific instructions as contained in Annex IC of Regulation (EC) No 1013/2006.

${ }^{2)}$ If more than three carriers, attach information as required in blocks 5 (a), (b), (c).

3) When the person who arranges the shipment is not the producer or collector, information about the producer or collector shall be provided.

4) The relevant code(s) as indicated in Annex IIIA to Regulation (EC) No 1013/2006 are to be used, as appropriate in sequence. Certain Basel entries such as $B_{1100}, B_{3010}$ and $B_{3020}$ are restricted to particular waste streams only, as indicated in Annex IIIA.

5) The BEU codes listed in Annex IIIB to Regulation (EC) No 1013/2006 are to be used. 
Nordic Council of Ministers

Ved Stranden 18

DK-1061 Copenhagen K

www.norden.org

\section{Shipments of green-listed waste}

This project was carried out to provide a better picture of transboundary shipments of green-listed waste involving project countries Denmark, Finland, Norway, and Sweden. The readily available export data for 2014 are presented. The primary effort in the project was devoted to an Annex VII inspection, which was carried out as a desk study. 33 companies were asked to send all their Annex VIls and related contracts from September-October 2015 to the competent authority of their country. Special focus was given to companies exporting waste beyond the EEA, as were the waste streams consisting of metal scrap, plastics, paper, and cable waste. In addition to the Annex VII inspection and the gathering of national statistics, the project included asking company representatives about their practices and opinions related to green-listed waste shipments, via a Web-based survey. 